Article

\title{
Set Thine House in Order: Black Feminism and the Sermon as Sonic Art in The Amen Corner
}

\author{
Melanie R. Hill
}

English Department, Rutgers University, New Brunswick, NJ 08901, USA; melhill@sas.upenn.edu

Received: 12 March 2019; Accepted: 11 April 2019; Published: 16 April 2019

\begin{abstract}
In The Souls of Black Folk, W.E.B. DuBois discusses the historical and cultural beginnings of the black preacher as "the most unique personality developed on American soil." He writes, "[the black preacher] found his functions as the healer of the sick, the interpreter of the Unknown, the comforter of the sorrowing, the supernatural avenger of wrong ... Thus as bard, physician, judge, and priest within the narrow limits allowed by the slave system rose the Negro preacher." Far from being a monolith, the preacher figure embodies many complexities and variances on how the preached Word can be delivered. This begs the question, in what ways can we reimagine DuBois's black preacher figure in his words, "the most unique personality developed on American soil," as a black woman? What remains to be seen in scholarship of the mid-twentieth century is an articulation of the black woman preacher in African American literature. By reimagining and refiguring a response to DuBois's assertion above, how is the role of the black woman preacher and impact of her sermons portrayed in African American literature? Using the art of the sermon, the intersection of music, and James Baldwin's The Amen Corner as a central text, this article examines the black woman preacher in character and African American women's spirituality in twentieth century literature. I argue that the way in which Margaret Alexander, as a black woman preacher in the text, creates sermonic spaces of healing and restoration (exegetically and eschatologically) for herself and others outside of the church becomes a new mode of social and cultural resistance. This article works to re-envision the black woman and reposition her in the center of religious discourse on our way to unearthing the modes of transfiguration black women preachers evoke in and out of the pulpit.
\end{abstract}

Keywords: the amen corner; james baldwin; black feminism; sermon; art; literature; music; black preacher; spirituality; religion

"...who is more deserving of admiration than the black woman, she who has borne the rigors of slavery, the deprivations consequent on a pauperized race, and the indignities heaped upon a weak and defenseless people. Yet she has suffered all with fortitude, and stands ever ready to help in the onward march to freedom and power. Be not discouraged black women of the world, but push forward, regardless of the lack of appreciation shown you. A race must be saved, a country must be redeemed ..."

-Amy Jacques Garvey

"In the absence of vaulted ceilings, stained glass windows and other pleasures of the eyes the black preacher's spoken word becomes the vehicle through which insurgent and dispossessed listeners encounter the sublime."

-Reverend Dr. Crystal J. Lucky

According to W.E.B. DuBois's 1903 publication of The Souls of Black Folk, the "Negro church of to-day is the social centre of Negro life in the United States, and the most characteristic expression of African character." (DuBois 2015) More explicitly, the black church is also defined as "the crucible 
in which the systematic faith affirmations and the principles of biblical interpretation have been revealed." (Cannon 1985) The church in general, but the black church in particular, represents a place of refuge, solace, and activism. It is a place where strategies of resistance to oppression, subjugation, and denigration are talked about, formed, and implemented. The church—the black church—serves as an implement of healing and restoration from the "troubles of this world."

In 1903, DuBois's statement was a true, conceptual representation of the theological nexus of the black community. Men led their congregations in song and Scripture, while the women prayed and listened to the fiery admonition of the preacher who with crescendoing claps, a thunderous dance, hoarse voice, and perspiring palms raised to the heavens, called for freedom and reformation from hegemony and white supremacy for his community. One hundred sixteen years later, the makeup of the black church has changed. While some of DuBois's descriptions concerning the church remain the same, other illustrations have been altered. Prayers of hope, songs to sooth the soul, and shouts of praise are still extant, but the cry for freedom visions lingers. The resonant sound of the freedom visions cry ranges from a pianissimo snivel to a fortissimo wail. It rings in the ears of this nation like a cacophony, jarring the hearing and visibility of the black community that yearns to be pulled back into united harmony. How does the black woman preacher figure in African American literature release that marginalization, render her voice free and herself visible from invisibility?

In "Of the Faith of Our Fathers", W.E.B. DuBois describes the black preacher figure at length in The Souls of Black Folk as "the most unique personality developed by the Negro on American soil." (DuBois 1903) By reading this passage, one is led to assume the black preacher figure can only be envisioned as male. What remains to be seen in the canonical scholarship of the early twentieth century is an articulation of the black woman preacher. The impact of the black woman's sermon in African American literature is equally meaningful in scholarly conversation, for the "black sermon is the mother's milk of African American discourse." (Appiah and Gates 1999)

Preaching and the black church have been a fundamental part of black life since slavery was established in America during the 1600s. (Cannon 1995) Black preachers provided a realm for both leadership and authority, whose credibility went unquestioned within the space of the church. There, the performativity of the preacher could render the black body visible in a period where black people and everything that characterized them were deemed invisible. Black preaching and the black church have been essential to black life, serving as realms of leadership and authority that black people as slaves did not have externally but could themselves occupy within the space of the church. ${ }^{1}$ Far from being a monolith, the preacher figure embodies many complexities and variances on how the preached Word can be delivered. This begs the question, can we imagine DuBois's black preacher figure in his words "the most unique personality on American soil" as a black woman? What sorts of nuances and varied possibilities do we need to place in the foreground in order to imagine black women as preacher figures and as the epitomes of moral authority? A question such as this requires that we re-envision the black woman and reposition her in the center of religious discourse on our way to unearthing the modes of transfiguration black women evoke via sermon and song, in and out of the pulpit.

In Cleophus J. LaRue's The Heart of Black Preaching, one has to match the connection between the sermon in black preaching and African American life. When the black preacher prepares to deliver Scripture and exegete it in such a way that the listener comprehends, there is an element in black preaching that cannot escape the discussion of black life in the sermon. In carefully exegeting a sermon, the preacher will both point to Scripture and the social occurrences of black life. In order to understand

1 Dr. Cannon writes in her exposition of black preaching and the church that the black community had a religious cultural that belonged to them. Amalgamating West African religious traditions and orthodox Christianity, "...black men and women developed an extensive religious life of their own. The Black church was the only social institution in which African Americans could exercise leadership and power, and the preacher and preaching were held in the highest esteem in the Black church community. "...The Black preacher served as the arbiter of intellectual/moral life and the principal interpreter of canonized sacred writings." (115) 
black preaching, one must understand the context in which that sermon is delivered. There is always intentionality behind the delivery of a particular sermon. LaRue writes, "While it is true that most black theologizing takes place in the pulpit, it is also true that a certain type of experiential brooding occurs in the embryonic stage of the sermon prior to the actual exegesis of the text. This deliberate, subliminal musing is an essential ingredient in the creation of the black sermon." ${ }^{2}$ In his analysis of black preaching in general, LaRue lays the groundwork for understanding two very important points in black preaching: the preacher's incorporation and exegetical emphasis of black social reality in the sermon and its pertinence to Scripture and how the text of the sermon "... impacts the sense in which God is believed to be present in and through scripture." ${ }^{3}$

This article investigates a black woman preacher protagonist in James Baldwin's first play, The Amen Corner (1954). Situating this work in an historical context, The Amen Corner can be understood as a Civil Rights Movement work written in the 1950s during the integration of public schools in the United States with Brown v. Board of Education I and II. ${ }^{4}$ When the play is published, Baldwin gives readers a black woman preacher in literature at a time when the black male preacher becomes synonymous with the Civil Rights Movement.

Having contextualized this work, this article examines the exegetical and eschatological approaches to Scriptures employed by Margaret Alexander, black woman preacher protagonist in Baldwin's play. This article also considers Margaret's respective approach to preaching, the mechanics and expressivity of her sermonic delivery, and in the process, looks beyond the sacred agenda of her sermons in order to foreground the black feminist cultural and social work her sermons perform. In addition, the musicality of the sermonic text and its delivery are suggestive of what I am calling a blues sensibility. Hence, I use the term black feminist blues consciousness to demonstrate the affective power blues music exerts in this play. Augmenting the concept of blues sensibility, I recognize the necessity to go beyond the traditional blues idiom of blues and melancholic expressions to examine how joy, mobility, agency are found in the blue note. Building on what Dr. Otis Moss, III calls the blue-note sensibility, I examine the sermonic practices to be found in Baldwin's play. ${ }^{5}$ Using The Amen Corner as a central text, this article analyzes the use of the sermon in Baldwin's play and the ways in which black feminism plays an efficacious part in the denouement of the text. Further, this essay evinces that irrespective of her location, Margaret Alexander remains a preacher and the impact of her sermons can be felt even when she leaves the church.

Throughout the play, Baldwin shows how Margaret, through her sermons, counters the hegemonic structures of racism, sexism, and classism that make women of color and particularly the voices of black women invisible within the church. As an authoritative presence in her own church, Baldwin evinces Margaret constantly fighting hegemony. The same mode of healing for black women that occurs inside of the church should be the very same mode that reaches black women outside of the church-a sermonic balm-healing speech that concerns the needs of the black woman. However, the point of contention arrives where the spaces that black women look to for healing and restoration in the church are not extant. In fact, the spaces within the church become the very same spaces they, in the end, have to constantly fight against to prove their worth. The manner in which black women create sermonic spaces of healing and restoration outside of the church becomes the new mode of resistance that we see with Margaret in The Amen Corner.

2 LaRue continues to assert the importance of the black social experience and its incorporation into the sermon of the black preacher. These two elements are inseparable. This observation is particularly important in this chapter when examining the sermonic space of the black woman. The context of each sermon is crucial in order to comprehend fully the meaning and impact of the black woman's ministerial delivery and just how her sermon impacts society outside of the church (13). LaRue (14).

Brown v. Board of Education I and II convened in Topeka, Kansas in 1954 and 1955, respectively.

Dr. Moss defines Blue Note sensibility in Blue Note Preaching in a Post-Soul World: Finding Hope in an Age of Despair as the amalgamation of the "shout and moan." Moss asserts that there must be a reclamation of this Blue Note sensibility in postmodernity in order for prophetic preaching to take place. (22). 
The church for the black community represents a place of healing, a place of comfort and restoration, but what happens when that place that you know as home, does not feel like home anymore? What happens when that space of healing starts to become a space of regret and retraction? Margaret's feminist presence disrupts the church she leads, and Baldwin positions her in this time in this respective play to illustrate how gender is seen as a territory or terrain over which the Word or prophecy is fought.

Reverend Dr. Katie G. Cannon's chapter, "The Emergence of Black Feminist Consciousness," refers to black women as "moral agents." ${ }^{16}$ By marking the trajectory of the black woman's vocal emergence and need for her voice to counter degradation of the black community, Cannon provides an historical context of women's involvement in the church during slavery and of their informal interpretation of Scripture. These women weren't in the "pulpit," as formal titled preachers, but their work as "crusaders" of social advancement in the church spilled into their impact outside of the church, as well. ${ }^{7}$ Black women were essentially invisible under the white supremacist lens. It is within the structure of the black church that black women found a space for vocalizing social justice. ${ }^{8}$

In Chanta M. Haywood's chapter, "The Act of Prophesying: Nineteenth-Century Black Women Preachers and Black Literary History," she defines prophesying as "the appropriation of a perceived mandate from God to spread His word in order to advance a conscious or unconscious political agenda." In her argument, Haywood makes clear that there are scholars such as Evelyn Higginbotham, Bettye Collier-Thomas and others who have made breakthroughs in their discoveries of the religious work of black women. In addition, Haywood emphasizes the necessity of recognizing and acknowledging in scholarship the element of the prophetic in African American literature. The notion of the prophetic is often bypassed by academicians, but it is the prophetic in literature that speaks to the path of the African American narrative structure: (Haywood 2003)

“...we have paid little attention to how these women's prophesying influenced their literary strategies and approaches. Further, an analysis of prophesying as a religious rhetoric and literary trope could lead to new possibilities for interpreting African American literature, containing undercurrents of religion and religious rhetoric. Even more, little has been written that connects the idea of prophesying to the development of African American literary history in general and African American women's literary history in particular." ${ }^{\prime 9}$

6 What makes Dr. Cannon's text so fundamental to this chapter is her exploration of black women as "moral agents" in the face of struggle between the worlds of white supremacy and male domination. She writes, "The feminist consciousness of Afro-American women cannot be understood and explained adequately apart from the historical context in which Black women have found themselves as moral agents. By tracking down the central and formative facts in the Black woman's social world, one can identify the determinant and determining structures of oppression that have shaped the context in which Black women discriminately and critically interpret Scripture, in order to apprehend the divine Word from the perspective of their own situation. Throughout the history of the United States, the interrelationship of White supremacy and male superiority has characterized the Black woman's reality as a situation of struggle-a struggle to survive in two contradictory worlds simultaneously, one White, privileged, and oppressive, the other Black, exploited, and oppressed. Thus, an entangling of the Black religious heritage sheds light on the feminist consciousness that guides Black women in their ongoing struggle for survival." Katie G. Cannon, "The Emergence of Black Feminist Consciousness" (47).

7 In response to black feminist/womanist (to borrow Alice Walker's terminology) consciousness, Cannon makes clear the role of black women within the church as agents of social change and platforms of resistance. She writes, "The black woman as educator attended Sunday services at local churches, where she often spoke in order to cultivate interest in the Black community's overall welfare. Churchwomen were crusaders in the development of various social service improvement leagues and aid societies. They sponsored fund-raising fairs, concerts, and all forms of social entertainment in order to correct some of the inequities...in the Black community." (52).

8 "The Black woman began her life of freedom with no vote, no protection, and no equity of any sort. Black women, young and old, were basically on their own. The patterns of exploitation of the Black woman as laborer and breeder were only shaken by the Civil War; by no means were they destroyed. Throughout the late nineteenth and early twentieth centuries, Black women were severely restricted to the most unskilled, poorly paid, menial work. Virtually no Black woman held a job beyond that of domestic servant or field hand. Keeping house, farming, and bearing and rearing children continued to dominate all aspects of the Black woman's life. The systematic exclusion of Black females from other areas of employment served as confirmation for the continuation of the servile status of Black women." (Cannon 51).

9 Haywood, 17 
Additionally, this essay conveys the blues music essence in the preaching of the black woman in literature. Using Moss, Cone, Cannon, and other scholars' assertions of blues music, I examine the amalgamation between the blues sensibility in preaching and black feminism, pinpointing those minor tonal notes within the sermon that sing in and past oppression of the black woman's voice and body to create a space that marks the freedom of the black woman in mind, body, and spirit.

Born in Harlem in 1924 into a religious and strict childhood, James Baldwin was the eldest of nine children. Amiri Baraka fervently deemed him as "God's black revolutionary mouth." The language of the church, patterns of the Bible and the struggles found in Scripture are significant characteristics of Baldwin's writing. In Baldwin's 1986 interview with Terry Gross, he delineates his three-year position as boy preacher in the pulpit:

And all of the elements which had driven me into the pulpit were still there-were still active. I was not less menaced. And in those three years in the pulpit-it's very difficult to describe them; I probably shouldn't try - ... there was a kind of torment in it. But I learned an awful lot. And I lost my faith, well the faith I had had. But I learned something else. I learned something about myself, I think. And I learned something through dealing with those congregations. After all I was a boy preacher. And the people whose congregations I addressed were grown-ups. Boy preachers have a very special aura in the black community and the aura implies a certain responsibility and that responsibility above all to tell the truth. So as I began to be more and more tormented by my crumbling faith it began to be clearer and clearer to me that I had no right to stay in the pulpit. (Baldwin 1986)

In his play, the church is Baldwin's armor for writing and the performance of the people are his tools for composing the text. Almost every novel and play that Baldwin writes is contingent upon the church and its imperfections; those imperfections are evinced most clearly in The Amen Corner. He uses the sermon and the black woman preacher figure to reveal that the inconsistencies within the church are the same incongruities in the secular world. Baldwin reveals:

I was armed, I knew, in attempting to write the play, by the fact that I was born in the church. I knew that out of the ritual of the church, historically-speaking, comes the act of the theatre, the communion which is the theatre. And I knew that what I wanted to do in the theatre was to recreate moments I remembered as a boy preacher, to involve the people, even against their will, to shake them up, and hopefully, to change them. I knew that an unknown black writer could not possibly hope to achieve this forum. (Baldwin 2013e)

Albert Murray's chapter, "The Blues as Music," gives a clear sense of what it means to have joy in the blues or to have joy in the morning. When the blues as music is generally defined, it is thought of as lugubrious, whining, complaining, downtrodden, dismal, dark compositions saturated with minor scale inflections; however, this spiritual aspect of joy coming during mourning or joy coming in the morning is the direct application of the blues to Baldwin's work and to Margaret sermons:

But as preoccupied with human vulnerability as so many of its memorable lyrics have always been, and as suggestive of pain as some of its instrumentation sometimes seems to be, blues music can hardly be said to be synonymous with lamentation and commiseration. Not when the atmosphere of earthiness and the disposition to positive action it engenders are considered. And besides, sometimes the lyrics mock and signify even as they pretend to weep, and as all the finger snapping, foot tapping, and hip cocking indicate, the instrumentation may be far less concerned with agony than with ecstasy. (Murray 2017)

In The Spirituals and the Blues, Reverend Dr. James H. Cone defines the blues as music "about black life and the sheer earth and gut capacity to survive in an extreme situation of oppression." (Cone 1972a) Dating the blues back to the late nineteenth century, Cone further defines the blues as "the essential ingredients that define the essence of the black experience" (Cone 1972b) 
And to understand them, it is necessary to view the blues as a state of mind in relation to the Truth of the black experience": Like the spirituals, the blues affirm the somebodiness of black people, and they preserve the worth of black humanity through ritual and drama. The blues are a transformation of black life through the sheer power of song. They symbolize the solidarity, the attitudes, and the identity of the black community and thus create the emotional forms of reference for endurance and esthetic appreciation. ${ }^{10}$

The blues is a significant style of preaching in the black church. Blues music is an art form characteristic of despair, loneliness, torment, distress, pain, and sorrow, but out of this blues, out of this sorrow, and out of this pain, emerges a sound that transgresses despair and brings joy. It appears oxymoronic to have joy emanate from the blues, but this marks the narratives and the trajectory of a practice that exegetically reflects sermons of pain that turn into proclamations of joy and sermons of anguish that turn into declarations of triumph. ${ }^{11}$ The sermons of Margaret mark specific sounds and particular notes that carry on the tradition of blues sung by black women. Black women sing their pain, anguish, sorrow, and grief. There was a particular joy that emanated from singing out the sting and pain of racism and misogyny. Not only was singing a way to ease out the heartache, but preaching proved a way to massage and assuage the burdens of the black woman.

Reverend Dr. Otis Moss, III defines black preaching as “...a unique cultural narrative and theological enterprise where African motifs meet diverse western influences of North America. A beautiful, bold, homiletical voice, poetry, prophetic witness, southern storytelling, lament, blues, and celebration are born out of this tradition." (Moss 2015) Blue note sensibility preaching is a homiletical sermonic style that amalgamates both, as Moss terms, the blues moan and the gospel shout. This amalgamation leads to a prophetic style of sermonic delivery that leaves a trace of hope in spaces of grievance.

Through the sermons of Margaret, I extend Moss's blue note sensibility term by providing a sense of the blue note as "other." Blues music with roots in African-American music, theory-wise, does not belong to the natural scale; it is a minor or flattened "out note." Blue notes are sounds that are dissonant and "don't belong."12 In relation to blues sensibilities within the sermon of the black women preachers in Baldwin's works, their sermons and their lives, as witnessed in The Amen Corner, are filled with blue notes-modes of not belonging, marginalization, denigration by white supremacy and also by men in their families, churches, and communities.

Baldwin's 1954 play, The Amen Corner, reflects the traditions of the black church and how those traditions are displayed in the home. Set in a Harlem church in the 1950s, Baldwin writes the story of single mother, Sister Margaret Alexander, who is the prominent leader and preacher of her church, but she struggles with keeping things together at home. Her ex-husband, Luke, returns to her life and her son, David, desires a career as a jazz musician. David wants to follow in his estranged father's footsteps, but Margaret sees the annihilating path (in her eyes) her son is travelling and attempts to keep him in the church and out of the "world." Margaret's position of prominence within the church is

10 Cone, (117).

11 In one of the pieces of writing in The Cross of Redemption, Baldwin explains in "The Uses of the Blues" the meaning of the blues as an art form in song. He makes clear in this context that a "toughness" exists in the blues that makes the experience of the artists singing it real: "I am engaged, then, in a discussion of craft or, to use a very dangerous word, art. And I want to suggest that the acceptance of this anguish one finds in the blues, and the expression of it, creates also, however odd this may sound, a kind of joy. Now joy is a true state, it is a reality; it has nothing to do with what most people have in mind when they talk of happiness, which is not a real state and does not really exist. Consider some of the things the blues are about. They're about work, love, death, floods, lynchings; in fact, a series of disasters which can be summed up under the arbitrary heading 'Facts of Life.'” (70-71)

12 In a regular major tonic scale, all notes are in harmony with each other; however, when a "blue note" is inserted which is a flattened third of flattened fifth, it is considered as an "out note." The blues scale "...had its roots in Afro-American music with the slaves and really became used in Blues, receiving the name of 'Blues scale.' The term 'blue note' is generally translated into Portuguese as an 'out note,' due to the fact of this note not [belonging] to [the] natural scale." (simplifyingtheory.com/blues-scale-blue-note). 
challenged by her son's rebellion at home. As a black woman whose position of authority is countered within the church and within her own domestic space, Baldwin allows us from a theatrical perspective to get a glimpse into Margaret's quest for the keys to the kingdom. ${ }^{13}$ The kingdom represents love and immersing one's self in love is the ultimate endeavor here: "[Margaret's] triumph...is that she sees this finally and accepts it, and, although she has lost everything, also gains the keys to the kingdom. The kingdom is love, and love is selfless, although only the self can lead one there. She gains herself." (Baldwin 2013e) Although Margaret loses her church, her husband, and perhaps even her son in the play, she gains herself-she gains love of herself. This is what Baldwin defines as the keys to the kingdom.

How Luke, Margaret's ex-husband, and David (Margaret's son) battle with each other in each scene of the play marks an already rocky start to the illustration of the preacher's house. Baldwin writes in his introduction that this play reflects much of what happened in his own life with respect to his own relationship with his stepfather. ${ }^{14}$ Baldwin only wanted his stepfather's love. His stepfather was a preacher, yet because of Baldwin's private life, it was challenging for Baldwin to find love from his father. In The Amen Corner, Baldwin takes his own story but instead of narrating a black man as the preacher, he tells the story of Luke's mother as the preacher. The preacher in this instance is seen as the enforcer, the ruler, the regulator; Margaret is forced to occupy the role as "leader" and "breadwinner" of her own house- a traditional position that usually men occupy in the household, especially in the 1950s. Yet from Baldwin's own words, it is through the portrayal of the black woman preacher in this text that dismantles the traditional role of the black woman in 1950s African-American literature.

As The Amen Corner takes place over the course of a week in Harlem, both the church and Sister Margaret's house are set within the same unit. From its literary illustration, the pulpitum or pulpit takes up the most room in the church. A chair fit for a high priestess sits atop the platform. As the congregants enter the church, a blues melody entitled "The Blues is Man" is heard. This sonic blues filling the air as bodies enter the sacred space of the church portends the developing contention in both Margaret's domestic and spiritual spaces. ${ }^{15}$ Before Margaret's first sermon on 2 Kings chapter 20, the choir sings with raised voices of God's care. The first song that Baldwin includes gives a musical preface to Margaret's first sermon, Set Thine House in Order. The choir sings jubilantly,

One day I walked the lonesome road

The spirit spoke unto me

And filled my heart with love,

Yes, he filled my heart with love,

And he wrote my name above,

And that's why I thank God I'm in His care.

(CHORUS)

Let me tell you now

Whilst I'm in His care,

Jesus got His arms wrapped around me,

No evil thoughts can harm me

13 "Keys to the Kingdom" is a recurring mantra in The Amen Corner as a response to Margaret's last sermon on love and the necessity to love both God and man.

14 "The first line written in The Amen Corner is now Margaret's line in the Third Act: 'It's a awful thing to think about, the way love never dies!' That line, of course, says a great deal about me- the play says a great deal about me-but I was thinking not only, not merely, about the terrifying desolation of my private life but about the great burdens carried by my father. I was old enough by now, at last, to recognize the nature of the dues he had paid, old enough to wonder if I could possibly have paid them, old enough, at last, at last, to know that I had loved him and had wanted him to love me. I could see that the nature of the battle we had fought had been dictated by the fact that our temperaments were so fatally the same: neither of us could bend. And when I began to think about what had happened to him, I began to see why he was so terrified of what was surely going to happen to me. The Amen Corner comes somewhere out of that." (15).

15 Before Margaret begins her first sermon and the choir sings "I'm So Glad I'm in His Care," Baldwin writes that a blues melody can be heard, "The Blues is Man" at sunrise. This blues insertion is especially important before the preacher's first sermon, portending what's to come over Margaret's house if she doesn't set it in order. 
'Cause I'm so glad I'm in His care. (Baldwin 2013a)

Stepping up to the pulpit as she meets her congregation with resounding, repeated cries of exaltation, Margaret's first sermon entitled, "Set Thine House In Order" comes from 2 Kings Chapter 20, an exegetical and eschatological illustration of the urgency that besets Margaret's own house. ${ }^{16}$ In this Scripture, King Hezekiah becomes gravely ill. He receives a prophecy from Isaiah saying, "Thus says the Lord: 'Set your house in order, for you shall die and not live.'"17 King Hezekiah begins to pray after turning his face to the wall and says, " ... 'I pray, how I have walked before You in truth and with a loyal heart, have done what was good in Your sight.'"18 Isaiah returns to Hezekiah from the Lord's command and tells him the Lord heard his prayer and as a result of the Lord adding fifteen years to Hezekiah's life, he is made well. In this sermon, Margaret preaches the importance of going to people who you know will pray for you-people who you know have a connection to God. Throughout the first sermon exists a call and response reminiscent of the black church choral tradition. The congregation meets her words with resounding responses of agreement, "Amen! Amen!" She tells her congregation,

Now when the king got the message, amen, he didn't do like some of us do today. He didn't go running to no spiritualists, no, he didn't. He didn't spend a lot of money on no fancy doctors, he didn't break his neck trying to commit himself to Bellevue Hospital. He sent for the prophet, Isaiah. Amen. He sent for a saint of God. (Baldwin 2013b)

Margaret delivers a sermon of simplicity and comprehension, one to which her congregation can relate, but her words are like a hammer that dissolves the rock of immorality into diminutive pieces. Gesturing to her congregation with both hands, Margaret continues to preach:

I know some of you think Sister Margaret's too hard on you. She don't want you to do this and she won't let you do that. Some of you say, 'Ain't no harm in reading the funny papers.' But children, yes, there's harm in it. While you reading them funny papers, your mind ain't on the Lord. And if your mind ain't stayed on Him, every hour of the day, Satan's going to cause you to fall. Amen!... But a saint of God ain't got no business delivering liquor to folks all day-how you going to spend all day helping folks into hell and then think you going to come here in the evening and help folks into heaven? It can't be done. The Word tells me, No man can serve two masters! (Baldwin 2013c)

The contrast and conflict evident in Margaret's first sermon as she admonishes her flock to abandon contradictory ways is the same division that is illustrated in her own house. The divisiveness in her sermon breaks apart and displays the fissures of not only the people under her care in the church, but also the people under her influence in her own home. Baldwin uses these chasms in Margaret's sermon to show the collapsible pulpit on which she stands. The choral selection before her sermon "I'm So Glad I'm in His Care" is a gospel blues song recorded and written in 1941 by legendary gospel musician Sister Rosetta Tharpe. The figure in the song walks a lonesome road until his or her heart is filled with love. The double emphasis on "Yes, he filled my heart with love" is a sonic prophecy that Margaret encounters towards the end of the play. Baldwin chooses a song written by a gospel blues black woman musician to preface Margaret's "Set Thine House in Order" sermon. The blues music heard outside of the church, "The Blues is Man," illustrates the blue notes awaiting Margaret and her

16 Margaret's first sermon, "Set Thine House in Order," comes from 2 Kings Chapter 20:1. In this passage, King Hezekiah's life is extended after he prays to God to deliver him from death. Isaiah, the prophet, comes to Hezekiah while he is sick and tells him what the Lord says, "'Set your house in order, for you shall die, and not live.'” After the prophecy from Isaiah, King Hezekiah turns his face to the wall and prays to God to remember how he's walked in truth and loyalty in the eyes of the Lord. After King Hezekiah's prayer, the Lord tells Isaiah to return to Hezekiah and tell him that his life will be extended by 15 years. (2 Kings 20:1-20 NKJV).

172 Kings Chapter 20:1 (NKJV). Available online: www.biblegateway.com.

182 Kings Chapter 20: 2 (NKJV). Available online: www.biblegateway.com. 
entire family. It's as if the blues melody prefaces the contentious relationships she encounters with both her estranged husband and son. Instead of the blues illustrated in the figure of man; the blues, in this instance, can also be evinced as woman, a black woman preacher whose sacred (public) and secular (private) worlds soon collide. In this context, Baldwin conveys the uses of the blues and perhaps in this instance, the uses of the gospel blues.

Margaret ends her sermon with music reflective of the text she preached.

I got the holy spirit

To help me run this race.

I got the holy spirit,

It appointed my soul a place.

My faith looks up to heaven,

I know up there I'll see

The Father, the Son, the Holy Spirit

Watching over me. (Baldwin 2013d)

Just as Margaret's sermon and song penetrate the souls of the congregation with words as fire, the reaction of the congregation to the preached Word is like a strong, violent force of hand claps, foot stomping, shrieks of joy, hands waving loosely in the air, along with the zills of the tambourine shaking feverishly, having its own shout and holler. It is through Margaret's first sermon that we witness the preached word from Scripture acting as prophetic healing salve to her congregation, at the same time reflecting the hidden breaches in her own life.

The dichotomies of which Margaret preached are reflected in her life, as she's not only the breadwinner for her house but also the leader of her church. While the Amen Corner in her church shows unwavering support of her to her face, they surreptitiously converse about her actions behind her back. In this case, both Margaret's church and home suffer chasms. The "Amen Corner" is defined as a group of people who give "unwavering support." According to the Oxford English Dictionary, the Amen Corner is defined as "that part of a meeting-house occupied by persons who assist the preacher with occasional and irregular responses."19 To say Amen means, "it is so." The word "Amen" offers an affirming belief or response to something said. Baldwin writes the hypocrisy of "The Amen Corner" in this play, as individuals who appear to be in "your corner" speak against you, claiming and accusing you of wrong. After her first sermon, the elders of the church question how Margaret can travel to the sister church in Philadelphia and "heal" them with her words, but her own church appears to be suffering under her leadership, according to the elders. This instance of Margaret's congregation speaking of her disparagingly behind her back is an example of the leadership of the black woman being challenged not only in her own house but also in the church. This is also an example of the blues sensibility that Dr. Otis Moss, III refers to-despair that not necessarily comes out in Scripture here, but also arises after the impact of the sermon. Margaret experiences blues sensibilities in her daily encounters with her congregation, but it is through the sermon that "hope" arises for her in the midst of despair.

During this period, it was unheard of to have a black woman in a leadership position, notwithstanding a preacher in the church unless they were the "mothers" of the church. The men and women, but mostly the men, of the church stand out against Margaret and her hegemony and disapprove of the fruit that her preaching tree produces. Brother Boxer, one of the elders of the church proclaims with anguish,

The Word say, You going to know a tree by its fruit. And we ain't been seeing such good fruit from Sister Margaret. I want to know, how come she think she can rule a church when

19 Corner, Amen. OED. University of Pennsylvania Library Online Database. 
she can't rule her own house? That husband of hers is in there, dying in his sins, and that half-grown, hypocrite son of hers is just running all roads to hell. (Baldwin 2013f)

When Margaret is on the verge of losing the trust and faith of her congregants under her leadership, her older sister-Odessa-tells her to remember the vision. She admonishes Margaret to think back to the vision of the church she had before she lost the support of the Amen Corner. Margaret seems to be a woman of loss-loss of her husband and the loss of her son. She struggles to keep her house together. At the end of the play, Margaret does order her house-she may not be a pastor any longer, she may have lost the members of her congregation, but she did gain something and someone-love of herself, holding the keys to the kingdom.

The same way in which the hand of God delivers King Hezekiah from death after he prays fervently and turns his face to the wall reflects a similar order from Margaret. After Margaret realizes the elders of the church are having a meeting to depose her and she may lose her congregation, her sister, Odessa reminds her of the vision. She admonishes her of the time that it is to not be a woman but a winner:

Odessa: Maggie. It was you had the vision. It weren't me. You got to think back to the vision. If the vision was for anything, it was for just this day.

Margaret: All these years I prayed as hard as I knowed how. I tried to put my treasure in heaven where couldn't nothing get at it and take it away from me and leave me alone. I asked the Lord to hold my hand. I didn't expect that none of this would ever rise to hurt me no more. And all these years it just been waiting for me, waiting for me to turn a corner. And there it stand, my whole life, just like I hadn't never gone nowhere. It's a awful thing to think about, the way love never dies!

Odessa: You's got to pull yourself together and think how you can win. You always been the winner. Ain't no time to be a woman now. You can't let them throw you out of this church. What we going to do then? I'm getting old, I can't help you. And you ain't young no more, neither. (Baldwin 2013g)

In "The Politics of Black Feminist Thought," Patricia Hill Collins describes nineteenth-century writer, educator, abolitionist, and activist, Maria Stewart's assertion of the importance of black women's relationships within themselves and with each other as mothers, activists, and intellectuals. Collins quotes Stewart: "'O, ye mothers, what a responsibility rests on you!' Stewart preached, 'You have souls committed to your charge.... It is you that must create in the minds of your little girls and boys a thirst for knowledge, the love of virtue ... and the cultivation of a pure heart.'" (Collins 2000a) To Stewart, "the power of self-definition was essential, for black women's survivial was at stake."20 In the text, Odessa's words shift Margaret from the marginalized position of woman in which her church places her, to winner, helping Margaret in the play realize and redefine what it means to be a woman in general but a black woman preacher in particular. A winner is a victor, champion, conqueror, and heroine. Odessa helps Margaret implement what Patricia Hill Collins calls in Black Feminist Thought the "power of self-definition." This power is ultimately attained from within the self, but at times, the community of believers who don't let the vision inside die awakens this force. Collins refers to particular black women characters from Celie in Alice Walker's The Color Purple to Janie in Zora Neale Hurston's Their Eyes Were Watching God, who enact the power of self-definition through writing letters or through the performance of telling their stories. Collins writes:

According to many African-American women writers, no matter how oppressed an individual woman may be, the power to save the self lies within the self. Other Black women may assist a Black woman in this journey toward personal empowerment, but the ultimate

20 Collins (1). 
responsibility for self-definitions and self-valuations lies within the individual woman herself. (Collins 2000b)

Odessa helps Margaret redefine womanhood, displacing her outside of oppression and marginalization that the black woman endures to a space of victory, not defeat. While Odessa helps Margaret realize her true position, it is Margaret who finishes the duty of self-definition. After Luke's death, Margaret delivers her last sermon. When Luke dies, he and Margaret reconcile, but it is not until the last sermon in the play where she realizes what it means to grasp fully the keys to the kingdom: love of neighbor and love of self.

Margaret: Children. I'm just now finding out what it means to love the Lord. It ain't all in the singing and the shouting. It ain't all in the reading of the Bible. (She unclenches her first a little.) It ain't even-it ain't even-in running all over everybody trying to get to heaven. To love the Lord is to love all His children-all of them, everyone!-and suffer with them and rejoice with them and never count the cost!

(Silence. She turns and leaves the pulpit.)

Sister Moore: Bless our God! He give us the victory! I'm gonna feast on milk and honey.

(Margaret comes down the stairs. She stands in the kitchen. Odessa comes downstairs. Without a word to Margaret, she goes through Luke's room, taking off her robe as she goes. The lights dim down in the church, dim up on Margaret, as Margaret starts toward the bedroom, and falls beside Luke's bed. The scrim comes down. One or two people pass in the street.) (Baldwin 2013h)

Margaret cautions her congregation that even when they think the world is not watching them, their eyes are fixed on the actions of the Christian. She emphasizes the importance of her congregation to live holy, sanctified, and set apart from the "world." Baldwin writes Margaret Alexander's character out of inspiration from a South Carolina pastor at Mt. Calvary Assembly Hall of the Pentecostal Faith Church for All Nations, named Rosa Artimus Horn. Horn inspires the writing of The Amen Corner's protagonist, for Baldwin recalls his own conversion experience at Mt. Calvary, propelling him to connect the Pentecostal culture of spiritual expression to the culture of theater. Baldwin writes in his introduction to The Amen Corner: "I knew that out of the ritual of the church, historically speaking, comes the act of the theatre, the communion which is the theatre. And I knew that what I wanted to do in the theater was to recreate the moments I remembered as a boy preacher, to involve the people, even against their will, to shake them up, and, hopefully, to change them." (XVI) ${ }^{21}$

Margaret mentions the mantra "Set Thine House in Order" on two occasions in her first sermon. Baldwin purposefully writes this scriptural mantra of setting one's house in order because he wants us as readers to decipher the dichotomies and contradictions that beset the preacher's household. Baldwin is not only writing about a doctor, a lawyer, a secretary in these texts. He specifically chooses the black woman preacher figure in literature to position her at a level of high esteem only to reveal the imperfections that she has as a flawed woman preacher/character. In this context, black women were not necessarily placed in positions of eminence, leadership, and moral authority. For Baldwin to place a black woman in a position of high esteem, not only generally but particularly within the church, when black women's voices were not even welcomed in the pulpit, is telling to the kinds of realities and many inconsistencies that surround the black church, particularly in the relationship between black men and women in the church. Baldwin has a message here: it is the Word that these black women characters plant as seeds in the hearts of the congregation, but when they leave the church, their sermonic/preacherly presence becomes even more palpable outside the walls of ecclesia.

21 Baldwin's connection of the communion in church to the culture of theater is expressed in the preface to The Amen Corner. Hardy also refers to Baldwin's discourse of the communion of the church matching theater in his essay, "James Baldwin as Religious Writer: The Burdens and Gifts of Black Evangelicalism" (67). 


\section{No Greater Love}

"Love the Lord Your God with all your heart and with all your soul and with all your mind and with all your strength.' The second is this: 'Love your neighbor as yourself.' There is no commandement greater than these." 22

In reimagining the figure of the black woman preacher in African-American literature, readers witness Margaret's spiritual metamorphosis from the beginning to the end of the play. We begin to see her sermonic platform have greater depth for own body and spirit. Margaret enters the play as an imperfect, judgmental (in the eyes of her congregants) character in the pulpit, yet when she departs the pulpit at the end of the play and in her last sermon, she realizes that the house she needed to set in order was her own. When she realizes the true value of a sermon preached in love, not only did her perspective change but her newfound epiphany of what it means to love God and people resonates with the rest of her congregation, as well. The black women preachers of which Baldwin writes don't remain preachers in the conventional sense, yet they evolve outside of what the conventions of their position meant to them. Alexander leaves the church and gives her last sermon on love. Baldwin shows readers that Margaret is never fully herself in the beginning of the novel. What she learns most about herself is when she steps out of the confines of the pulpit into her own "power of self-definition." Margaret transforms as a character in the play and leaves the church from her own realization of the deep impact of self-definition and self-love. There is an evolution of the preacherly position here and Baldwin's critique of the church is reflected when Margaret leaves the church and steps outside of her traditional roles. Love of self and love of others augments Margaret's sermonic power and impact outside of the walls of the church. As readers, we begin to see the preacherly pulpit form more and more-with greater shape, greater depth and breadth. The arc of this play sees the pulpit get bigger-wider. However, the pulpit does not necessarily always come in the form of a platform in a magnanimous church edifice; rather, the pulpit is what the black woman makes it to be. The pulpit is that sermonic space where the black woman gives instruction and correction. The pulpit is where the black woman preacher then becomes visible, breaking down the wall of subjugation and invisibility with her words for others and for herself. Baldwin shifts our level of thinking that is locked into traditions of believing the man as the ultimate moderator of authority and brings in the black woman - the black woman who is often thought of as the mule of the world, who works, toils, travails assiduously, is castigated but is brought back as a renewed, powerful figure holding the keys to the kingdom.

Rather than present a monolith of the church, Baldwin illustrates the variances, imperfections and dissonance in the black church. In The Amen Corner, he presents the church as a multidimensional space with many layers that are uncovered from the immoral actions and betrayals of the congregation. Baldwin writes in his introduction to The Amen Corner that Sister Margaret's "sense of reality [was] dictated by society's assumption, which also becomes her own, of her inferiority. Her need for human affirmation, and also for vengeance, expresses itself in her merciless piety; and her love, which is real but which is also at the mercy of genuine and absolutely justifiable terror, turns her into a tyrannical matriarch." (Baldwin 2013e) Margaret voices most articulately the freedom that she "acquires" at the end of the play, and in the text, Margaret's sermons exhale upon dry bones, commanding herself and her listeners to hear the psalmic sound of the Spirit, to move with hind's feet as "historical agents" that effect change, and with eagle eyes watch God.

In conclusion, Baldwin's The Amen Corner illustrates through Margaret Alexander, the black woman preacher as blues heroine through a gospel-blues lens. Channeling Chanta M. Haywood's concept of the importance of recognizing the element of the prophetic in African American literature, Baldwin's entire oeuvre is often composed as prophecy; it is a sermonic trajectory of the African

22 Mark 12:30-31 (New International Version). 
Diaspora from the Middle Passage to the streets of Harlem and even to the twenty-first century. It is a call and response prophecy that speaks openly about the social and cultural issues of this nation from a sermonic platform. It is the reason why Amiri Baraka aptly labels Baldwin as "God's black revolutionary mouth," for Baldwin asserts, "To rule over and control the course of people's lives is an awesome responsibility. An emissary of God must practice the love of God...one who is incapable of love should not instruct. Love will overcome power ... To love man is to love God. To preach [the] love of God and live without the love of man will lead to disaster for the wrath of the righteous is great [inevitably]. The need of love is greater than the need of glory."23

Funding: This research received no external funding.

Conflicts of Interest: The author declares no conflict of interests.

\section{References}

Appiah, Anthony, and Henry Louis Gates. 1999. Africana: The Encyclopedia of the African-American Experience. Oxford: Oxford University Press, p. 728.

Baldwin, James. 2013a. The Amen Corner. New York: Vintage, p. 6.

Baldwin, James. 2013b. The Amen Corner. New York: Vintage, p. 8.

Baldwin, James. 2013c. The Amen Corner. New York: Vintage, pp. 9-10.

Baldwin, James. 2013d. The Amen Corner. New York: Vintage, p. 10.

Baldwin, James. 2013e. The Amen Corner. New York: Vintage, p. 16.

Baldwin, James. 2013f. The Amen Corner. New York: Vintage, p. 37.

Baldwin, James. 2013g. The Amen Corner. New York: Vintage, pp. 80-81.

Baldwin, James. 2013h. The Amen Corner. New York: Vintage, p. 88.

Baldwin, James. 1986. Terry Gross's Interview. Available online: https://www.youtube.com/watch?v= IWRuQ8CJOFg (accessed on 1 June 2017).

Cannon, Katie G. 1985. The Emergence of Black Feminist Consciousness. Feminist Interpretation of the Bible 47: $30-40$.

Cannon, Katie G. 1995. Katie's Canon: Womanism and the Soul of the Black Community. New York: Continuum International Publishing Group, p. 115.

Collins, Patricia Hill. 2000a. The Politics of Black Feminist Thought. In Black Feminist Thought: Knowledge, Consciousness, and the Politics of Empowerment, 2nd ed. New York: Routledge, p. 2.

Collins, Patricia Hill. 2000b. The Power of Self-Definition. In Black Feminist Thought: Knowledge, Consciousness, and the Politics of Empowerment, 2nd ed. New York: Routledge, p. 119.

Cone, James. 1972a. The Spirituals and the Blues. Ossining: Orbis Books, p. 108.

Cone, James. 1972b. The Spirituals and the Blues. Ossining: Orbis Books, p. 114.

DuBois, William Edward Burghardt. 1903. Of the Faith of Our Fathers. In The Souls of Black Folk. London: Routledge, p. 120.

DuBois, William Edward Burghardt. 2015. The Souls of Black Folk. London: Routledge, p. 121.

Haywood, Chanta M. 2003. Prophesying Daughters. Columbia: University of Missouri Press, p. 17.

Moss, Otis. 2015. Blue Note Preaching in a Post-Soul World. Louisville: Westminster John Knox Press.

Murray, Albert. 2017. The Blues as Music. In Stomping the Blues. Minneapolis: U of Minnesota Press, p. 51.

(C) 2019 by the author. Licensee MDPI, Basel, Switzerland. This article is an open access article distributed under the terms and conditions of the Creative Commons Attribution (CC BY) license (http://creativecommons.org/licenses/by/4.0/).

23 Baldwin Archives at the Schomburg Center in Harlem, NY (Box 29; Folder 9; Page 5). 